\title{
A morphological and molecular characterization of vine mealybug populations (Hemiptera, Pseudococcidae) from Tunisia
}

\author{
R. Mansour, ${ }^{1,2}$ V. Cavalieri, ${ }^{1}$ G. Mazzeo, ${ }^{1}$ K. Grissa Lebdi, ${ }^{2}$ A. Russo' \\ ${ }^{1}$ Dipartimento di Gestione dei Sistemi Agroalimentari e Ambientali, Sezione Entomologia Agraria, \\ Università degli Studi di Catania, Italy; ${ }^{2}$ Department of Plant Protection and Post-harvest \\ Diseases, Laboratory of Entomology, National Agronomic Institute of Tunisia, University \\ of Carthage, Tunis, Tunisia
}

\begin{abstract}
Some vine mealybug, Planococcus ficus (Signoret) populations in Tunisian vineyards have been morphologically and genetically characterized. The morphological examination was based on the main distinctive characteristics of species of Planococcus, namely the number and distribution of the multilocular disc pores and tubular ducts on the adult female. This showed the existence of two different vine mealybug populations in Tunisia. Likewise, in the molecular analyses, two separate clades were revealed in the neighbour-joining phylogenetic tree, supporting the morphological studies and suggesting that there are two distinct populations of $P$. ficus on grapevine in Tunisia.
\end{abstract}

\section{Introduction}

The Coccoidea (Hemiptera: Sternorrhyncha) contains nearly 8000 species of plant-feeding scale insects in up to 32 families (Gullan and

Correspondence: Ramzi Mansour, Department of Plant Protection and Postharvest Diseases, Laboratory of Entomology, National Agronomic Institute of Tunisia, University of Carthage, 43 Charles Nicolle Avenue, 1082 Cité Mahrajène, Tunis, Tunisia. E-mail: ramzi_mansour82@yahoo.co.uk

Key words: Planococcus ficus, morphological variation, genetic diversity, Vitis vinifera, Mediterranean basin.

Acknowledgements: we would like to thank everyone from the CRDA, CTV and CRA (Tunisian Ministry of Agriculture and Environment) and grapegrowers in the sites investigated in this study for their valuable collaboration. R.M. received a study grant from the AVERROES program (Erasmus Mundus, European Commission).

Received for publication: 20 December 2011.

Revision received: 20 March 2012.

Accepted for publication: 18 April 2012.

(C) Copyright R. Mansour et al., 2012

Licensee PAGEPress, Italy

Journal of Entomological and Acarological Research 2012; 44:e5 doi:10.4081/jear.2012.e5

This article is distributed under the terms of the Creative Commons Attribution Noncommercial License (by-nc 3.0) which permits any noncommercial use, distribution, and reproduction in any medium, provided the original author(s) and source are credited.
Cook, 2007). The most common families are those with the most species, namely the Diaspididae, Pseudococcidae and Coccidae (Kondo et al., 2008). Pseudococcidae (mealybugs) is the second most speciesrich family with 2291 species described (Ben-Dov et al., 2011). It is found worldwide and is considered the most economically important scale insect group infesting grapevine (Vitis vinifera L.) (Dalla Montà et al., 2001; Daane et al., 2006; Walton et al., 2009; Charles et al., 2010). More specifically, Planococcus ficus (Signoret) is considered to be the most serious mealybug threat to grapevine in many grape-growing areas around the world, e.g. Italy, Iran, California (USA), Argentina and South Africa (Trjapitzin and Trjapitzin, 1999; Dalla Montà et al., 2001; Daane et al., 2006; Moghaddam, 2006; Walton et al., 2009). Due to its phloem-feeding habit, $P$. ficus eliminates honeydew, which supports the growth of sooty mold fungi on leaf and fruit surfaces, thus inhibiting photosynthesis. Furthermore, $P$. ficus has been shown to transmit grapevine viruses (Mahfoudhi et al., 2009; Tsai et al., 2010).

Mealybugs are often impossible to identify in the field and have, therefore, been preserved in alcohol and then mounted on microscope slides for identification (Williams and Watson, 1988). Some species are morphologically very similar (e.g. P. ficus and P. citri, Risso) and identification using morphological characteristics can be difficult and/or inaccurate. For these reasons, molecular studies have recently been introduced to better discriminate and characterize some closely related mealybug species (Cavalieri et al., 2008; Hardy et al., 2008; Malausa et al., 2011). Such new molecular tools can complement and confirm the morphological studies.

In Tunisia, $P$. ficus and $P$. citri have been shown to coexist on grapevines within the same vineyard (Mansour et al., 2009) and $P$. ficus is now considered to be the most common mealybug species in vineyards in Tunisia (Mansour et al., 2011). However, there is still no published information on combined morphological and molecular studies of vine mealybug populations from Tunisia. In this context, the present study was undertaken to characterize some vine mealybug populations to be found in Tunisia to verify whether morphologically and genetically different populations of this insect occuring in some Tunisian grape-growing areas.

\section{Materials and methods}

\section{Sampling of mealybugs}

Sampling was carried out during the summer 2009 in 11 tablegrape vineyards belonging to 8 grape growing sites (Table 1). Most of the vineyards investigated were planted with the variety Muscat of Italy, a variety that is pergola trained and drip irrigated. Adult females were collected mainly from vine trunks and then preserved 
in small vials containing $70 \%$ ethanol until morphological or molecular characterization was carried out.

\section{Morphological characterization}

The mealybugs were prepared on microscope slides according to the method described by Williams and Watson (1988). For each sample vineyard, 20 slide mounted specimens (20 replicates) were selected for morphological characterization. The identification of mealybug species was performed using the keys of Tranfaglia and Tremblay (1982), Cox (1989) and Williams and Granara de Willink (1992). The main characteristics studied were those for discriminating between species in the genus Planococcus Ferris (Tranfaglia and Tremblay, 1982; Cox, 1989; Williams and Granara de Willink, 1992): the total number of multilocular disc pores on pro-, meso- and metathorax, and the number of tubular ducts on the head and near cerarii VIII (counting from the head). Thus, for each site, the population was characterized by the mean $(n=20)$ of each of the five characteristics mentioned above in order to highlight any morphological differences between mealybug populations belonging to different grape-growing sites. To compare the same characteristic between the different sites, data were analyzed using one-way ANOVA and the means separated using the Least Significant Difference (LSD)-test at $\mathrm{P}=0.05$. All statistical analyses were performed using Statistica 7.0 (StatSoft Inc., 2004).

\section{Molecular characterization}

Single mealybug individuals were subjected to total DNA extraction using Chelex 100 resin (BioRad), following the protocol described by Walsh et al. (1991) and modified by De Barro and Driver (1997). Each sample was homogenized in $40 \mu \mathrm{L}$ Chelex $5 \%$ and then incubated at $54^{\circ} \mathrm{C}$ for $15 \mathrm{~min}$ and at $98.8^{\circ} \mathrm{C}$ for $7 \mathrm{~min}$, before being cooled at $-20^{\circ} \mathrm{C}$ for $5 \mathrm{~min}$ and then centrifuged at 13,200 rpm for $10 \mathrm{~min}$. The supernatant containing DNA was recovered and was stored at $-20^{\circ} \mathrm{C}$ to be used for polymerase chain reaction (PCR) assay.

The relationship between different populations of $P$. ficus was investigated by amplification and sequencing of Ribosomal ITS1 region (Internal Transcribed Spacer 1). DNA amplification was conducted using TW81 forward primer: 5'-GTTTCCGTAGGTGAACCTGC-3' (Brust et al., 1998) and reverse primer 5.8R 5'-ATCCGCGAGCCGAGTGATCC-3' (De Barro et al., 2000). PCR reactions were conducted in $21 \mu \mathrm{L}$ volumes with $8.5 \mu \mathrm{L}$ buffer premix $2 \times$ F (FailSafe $^{\mathrm{TM}}$ PCR Premix Selection Kit, Epicentre Technologies), $1 \mu \mathrm{L}$ of each primer $(10 \mu \mathrm{M}), 0.5 \mu \mathrm{L}$ Taq polymerase (Invitrogen) and $2 \mu \mathrm{L}$ DNA template. The cycle parameters were: $94^{\circ} \mathrm{C}$ for $5 \mathrm{~min}$, then 30 cycles at $94^{\circ} \mathrm{C}$ for $1 \mathrm{~min}, 52^{\circ} \mathrm{C}$ for $1 \mathrm{~min}, 72^{\circ} \mathrm{C}$ for $1.5 \mathrm{~min}$. PCR products were run in $1.6 \%$ agarose gel and highlighted with SYBR $^{\circledR}$ Safe DNA gel stain (Invitrogen). PCR products of approximately 500 bp were sequenced by BMR Genomics sequencing service (Padua, Italy) and analyzed through neighbor-joining (Saitou and Nei, 1987) and Tamura-Nei distances as implemented in MEGA5 (Tamura et al., 2011). The citrus mealybug $P$. citri was used as the outgroup.

\section{Results and discussion}

Statistical analyses did not reveal any differences between vine mealybug populations in either the number of tubular ducts on head (F5, 114=1.22; $\mathrm{P}=0.3$ ) or near cerarii VIII (F5, 114=1.95; $\mathrm{P}=0.08$ ) (Table 2). By contrast, significant differences were found in the total number of multilocular disc pores on the prothorax (F5, 114=4.26; $\mathrm{P}=0.01)$, on the mesothorax ( $\mathrm{F} 5,114=5.41 ; \mathrm{P}=0.0001$ ) and on the metathorax ( $F 5,114=10.74 ; \mathrm{P}<0.0001$ ). Overall, the number of multilocular disc pores on $P$. ficus was significantly lower in populations

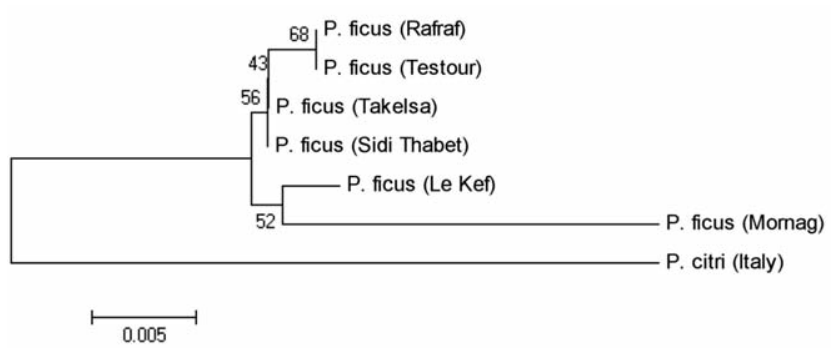

Figure 1. Molecular characterization. Neighbour-joining phylogenetic tree of vine mealybug Planococcus ficus populations from six vine areas in Tunisia. P. citri, was used as the outgroup.

Table 1. Tunisian table-grape growing areas sampled (summer 2009).

\begin{tabular}{lccc}
$\begin{array}{l}\text { Grape-growing } \\
\text { site }\end{array}$ & $\begin{array}{c}\text { Geographic } \\
\text { coordinates }\end{array}$ & $\begin{array}{c}\text { N } \\
\text { vineyards }\end{array}$ & $\begin{array}{c}\text { Sampling } \\
\text { date }\end{array}$ \\
Mornag & $36^{\circ} 41^{\prime} 7.04^{\prime \prime} \mathrm{N}, 10^{\circ} 17^{\prime} 17.01$ 'E & 3 & $16 / 6 ; 2 / 7 ; 28 / 8$ \\
Takelsa & $36^{\circ} 47^{\prime} 24^{\prime \prime} \mathrm{N}, 10^{\circ} 37^{\prime} 48^{\prime \prime} \mathrm{E}$ & 1 & $27 / 6$ \\
\hline Le Kef & $36^{\circ} 10^{\prime} 45.38^{\prime \prime} \mathrm{N}, 8^{\circ} 42^{\prime} 50.9^{\prime \prime} \mathrm{E}$ & 1 & $30 / 6$ \\
Sidi Thabet & $36^{\circ} 54^{\prime} 50^{\prime \prime} \mathrm{N}, 10^{\circ} 2^{\prime} 10^{\prime \prime} \mathrm{E}$ & 1 & $22 / 7$ \\
\hline Rafraf & $37^{\circ} 11^{\prime} 50.533^{\prime \prime} \mathrm{N}, 0^{\circ} 10^{\prime} 43.43^{\prime \prime} \mathrm{E}$ & 2 & $7 / 7$ \\
Testour & $36^{\circ} 33^{\prime} 17.38^{\prime \prime} \mathrm{N}, 9^{\circ} 26^{\prime} 41.49^{\prime} \mathrm{E}$ & 1 & $11 / 6$ \\
\hline Bousalem & $36^{\circ} 36^{\prime} 0^{\prime \prime} \mathrm{N}, 8^{\circ} 41^{\prime} 60^{\prime \prime} \mathrm{E}$ & 1 & $11 / 6$
\end{tabular}

Table 2. Mean number of tubular ducts on adult female vine mealybugs $(\mathrm{n}=20)$ from six vine growing areas in Tunisia.

\begin{tabular}{lcc}
$\begin{array}{l}\text { Grape-growing } \\
\text { site }\end{array}$ & $\begin{array}{c}\text { Mean n. }( \pm \text { SE) of } \\
\text { tubular ducts } \\
\text { on the head }\end{array}$ & $\begin{array}{c}\text { Mean } n \text {. ( } \pm \text { SE) of } \\
\text { tubular ducts near } \\
\text { cerarii VIII }\end{array}$ \\
Le Kef (NW) & $0.15 \pm 0.08$ & $1.5 \pm 0.32$ \\
Mornag (NE) & $0.2 \pm 0.09$ & $0.75 \pm 0.26$ \\
\hline Takelsa (NE) & $0.15 \pm 0.08$ & $0.8 \pm 0.22$ \\
Testour (NW) & $0.3 \pm 0.10$ & $1.7 \pm 0.40$ \\
\hline Rafraf (EN) & $0.45 \pm 0.20$ & $1.45 \pm 0.28$ \\
Bousalem (NW) & $0.1 \pm 0.07$ & $0.85 \pm 0.27$ \\
\hline
\end{tabular}

Within columns, there is no significant difference in the means at $5 \%$ level of significance $(P>0.05)$.

NW, north-west Tunisia; NE, north-east Tunisia; EN, extreme north of Tunisia. SE, standard error.

Table 3. Mean number of multilocular disc pores on adult female vine mealybugs $(n=20)$ from six vine growing areas in Tunisia.

\begin{tabular}{lccc}
$\begin{array}{l}\text { Grape-growing } \\
\text { site }\end{array}$ & $\begin{array}{c}\text { Mean n. } \\
( \pm \text { SE) of } \\
\text { multilocular } \\
\text { disc pores on } \\
\text { prothorax }\end{array}$ & $\begin{array}{c}\text { Mean n. } \\
( \pm \text { SE) of } \\
\text { multilocular } \\
\text { disc pores on } \\
\text { mesothorax }\end{array}$ & $\begin{array}{c}\text { Mean n. } \\
\text { multilocular } \\
\text { disc pores on } \\
\text { metathorax }\end{array}$ \\
Le Kef (NW) & $4.5 \pm 0.55^{\mathrm{a}}$ & $0.9 \pm 0.23^{\mathrm{a}}$ & $1.95 \pm 0.37^{\mathrm{a}}$ \\
Mornag (NE) & $5.05 \pm 0.89^{\mathrm{ab}}$ & $1.8 \pm 0.37^{\mathrm{ab}}$ & $3.7 \pm 0.67^{\mathrm{a}}$ \\
\hline Takelsa (NE) & $6.75 \pm 0.59^{\mathrm{bc}}$ & $4.5 \pm 0.83^{\mathrm{d}}$ & $6.7 \pm 0.7^{\mathrm{b}}$ \\
Testour (NW) & $7 \pm 0.68^{\mathrm{c}}$ & $3.4 \pm 0.61^{\mathrm{cd}}$ & $8.15 \pm 0.94^{\mathrm{b}}$ \\
\hline Rafraf(EN) & $7.85 \pm 0.65^{\mathrm{c}}$ & $2.9 \pm 0.49^{\mathrm{bc}}$ & $7 \pm 0.59^{\mathrm{b}}$ \\
Bousalem (NW) & $7.9 \pm 0.71^{\mathrm{c}}$ & $2.7 \pm 0.45^{\mathrm{bc}}$ & $6.35 \pm 0.83^{\mathrm{b}}$ \\
\hline
\end{tabular}

Within columns, there is no significant difference in means followed by the same letter at $5 \%$ level of significance (LSD test). NW, north-west Tunisia; NE, north-east Tunisia; EN, extreme north of Tunisia. SE, standard error. 
Table 4. Pairwise genetic distances between Planococcus ficus populations belonging to different sites. The citrus mealybug Planococcus citri was used as the outgroup.

\begin{tabular}{lccccccc} 
Specimens & $\begin{array}{c}\text { P. citri } \\
\text { (Italy) }\end{array}$ & $\begin{array}{c}\text { P. ficus } \\
\text { (Le Kef) }\end{array}$ & $\begin{array}{c}\text { P. fictus } \\
\text { (Mornag) }\end{array}$ & $\begin{array}{c}\text { P. ficus } \\
\text { (Sidi Thabet) }\end{array}$ & $\begin{array}{c}\text { P. ficus } \\
\text { (Takelsa) }\end{array}$ & $\begin{array}{c}\text { P. ficus } \\
\text { (Rafraf) }\end{array}$ & $\begin{array}{c}\text { P. ficus } \\
\text { (Testour) }\end{array}$ \\
P. citri (Italy) & 0.000 & 0.011 & 0.012 & 0.010 & 0.010 & 0.010 & 0.010 \\
P. ficus (Le Kef) & 0.048 & 0.000 & 0.007 & 0.003 & 0.003 & 0.004 & 0.004 \\
\hline P. ficus (Mornag) & 0.061 & 0.021 & 0.000 & 0.007 & 0.007 & 0.007 & 0.007 \\
P. ficus (Sidi Thabet) & 0.043 & 0.005 & 0.021 & 0.000 & 0.000 & 0.002 & 0.002 \\
\hline P. ficus (Takelsa) & 0.043 & 0.005 & 0.021 & 0.000 & 0.000 & 0.002 & 0.002 \\
P. ficus (Rafraf) & 0.046 & 0.007 & 0.023 & 0.002 & 0.002 & 0.000 & 0.000 \\
\hline P. ficus (Testour) & 0.046 & 0.007 & 0.023 & 0.002 & 0.002 & 0.000 & 0.000 \\
\hline
\end{tabular}

from the Le Kef and Mornag sites compared to populations from the sites at Takelsa, Testour, Rafraf and Bousalem (Table 3). More specifically, the most significant difference between these populations were found in the number of multilocular disc pores on the metathorax (Table 3).

These morphological results were supported by our molecular analysis. The neighbour-joining phylogenetic tree (Figure 1) shows that the $P$. ficus populations are clearly separated into two clades, suggesting that $P$. ficus is comprised of two genetically different populations on grapevine in Tunisia. Indeed, the mealybugs from the sites of Le Kef and Mornag (the pairwise genetic distances between these populations and the other four populations ranged from 0.005 to 0.023) were genetically different from populations collected from the sites at Rafraf, Takelsa, Sidi Thabet and Testour (pairwise genetic distances between these populations ranged from 0 to 0.002) (Table 4). Into this clade the genetic distances of the four population are very low. Using the Internal Transcribed Spacer 1 (ITS1) region, no genetic differences were found between the Rafraf and Testour populations or between the Takelsa and Sidi Thabet populations, respectively. Further studies are needed to confirm these results and facilitate recognition of the vine mealybug populations in Tunisia. These results sugest two possible hypotheses. First, that the populations from the Mornag and Le Kef sites are F1 hybrids from either the cross $P$. ficus females $\mathrm{x} P$. citri males or the cross $P$. citri females $\mathrm{x} P$. ficus males. In fact, to support this possible hypothesis, both male and female $P$. ficus and $P$. citri have been recorded from the same vineyard in Tunisia (Mansour, 2008; Mansour et al., 2009). If such hybrids were present on grapevines, then identification based solely on morphological characters would probably be difficult and might inaccurate identification, making it necessary to carry out molecular analyses for more accurate discrimination (characterization). Consequently, if further study does confirm the presence of two distinct morphs, then combining morphological and molecular analyses could be important. The second hypothesis might be that the two populations of $P$. ficus represent two different biotypes. In this context, performing biological crosses between males and females from each population would be useful to determine whether or not they are reproductively incompatible. Understanding how these morphological and molecular differences in P. ficus populations could influence bioecological traits is clearly important with regard to integrated pest management. Furthermore, differences in their ability to transmit grapevine viruses need to be evaluated. Further studies should be focused on carefully investigating other vine mealybug populations from vineyards throughout the Mediterranean basin, as this is the area of origin of this pseudococcid species. These would widen our understanding of the phylogenetic (evolutionary) relationships among vine mealybug populations from different Mediterranean countries.

\section{References}

BEN DOV Y., MILLER D.R., GIBSON G.A.B., 2011 - ScaleNet. A database of the scale insects of the world. Available from: http://www. sel.barc.usda.gov/scalecgi/chklist.exe?Family=Pseudococcidae\&g enus $=$

BRUST R.A., BALLARD J.W.O., DRIVER F., HARTLEY D.M., GALWAY N.J., CURRAN J., 1998 - Molecular systematic, morphological analysis and hybrid crossing identity a third taxon, Aedes (Halaedes) australis species-group (Diptera: Culicidae). - Can. J. Zoolog. 76: 1236-1246.

CAVALIERI V., MAZZEO G., TROPEA GARZIA G., BUONOCORE E., RUSSO A., 2008 - Identification of Planococcus ficus and Planococcus citri (Hemiptera: Pseudococcidae) by PCR-RFLP of COI gene. Zootaxa 1816: 65-68.

CHARLES J.G., BELL V.A., LO P.L., COLE L.M., CHHAGAN A., 2010 Mealybugs (Hemiptera: Pseudococcidae) and their natural enemies in New Zealand vineyards from 1993-2009. New Zeal. Entomol. 33: 84-91.

COX J.M., 1989 - The mealybug genus Planococcus (Homoptera: Pseudococcidae). Bull. Br. Mus. (Nat. Hist.) Entomol. 58: 1-78.

DAANE K.M., BENTLEY W.J., WALTON V.M., MALAKAR-KUENEN R., YOKOTA G.Y., MILLAR J.G., et al., 2006 - New controls investigated for vine mealybug. Calif. Agr. 60: 31-38.

DALLA MONTÀ L., DUSO C., MALAGNINI V., 2001 - Current status of scale insects (Hemiptera: Coccoidea) in the Italian vineyards. Boll. Zool. Agrar. Bachic. 33: 343-350.

DE BARRO J.P., DRIVER F., 1997 - Use of RAPD PCR to distinguish the B biotype from others biotypes of Bemisia tabaci (Gennadius) (Hemiptera: Aleyrodidae). Aust. J. Entomol. 36: 149-152.

DE BARRO J.P., DRIVER F., TRUEMAN J.W.H., CURRAN J., 2000 Phylogenetic relationship of world population of Bemisia tabaci (Gennadius) using ribosomal ITS1. - Mol. Phylogenet. Evol. 16: 29-36.

GULLAN P.J., COOK L.G., 2007 - Phylogeny and higher classification of the scale insects (Hemiptera: Sternorrhyncha: Coccoidea). Zootaxa 1668: 413-425.

HARDY N.B., GULLAN P.J., HODGSON C.J., 2008 - A subfamily-level classification of mealybugs (Hemiptera: Pseudococcidae) based on integrated molecular and morphological data. - Syst. Entomol. 33: $51-71$.

KONDO T., GULLAN P.J., WILLIAMS D.J., 2008 - Coccidology: The study of scale insects (Hemiptera: Sternorrhyncha: Coccoidea). Rev. Cor. Cienc. Tecnol. Agrop. 9: 55-61.

MAHFOUDHI N., DIGIARO M., DHOUIBI M.H., 2009 - Transmission of grapevine leafroll viruses by Planococcus ficus (Hemiptera: Pseudococcidae) and Ceroplastes rusci (Hemiptera: Coccidae). Plant Dis. 93: 999-1002. 
MALAUSA T., FENIS A., WAROT S., GERMAIN J-F., RIS N., PRADO E., BOTTON M., VANLERBERGHE-MASUTTI F., SFORZA R., CRUAUD C., COULOUX A., KREITER P., 2011 - DNA markers to disentangle complexes of cryptic taxa in mealybugs (Hemiptera: Pseudococcidae). - J. Appl. Entomol. 135: 142-155.

MANSOUR R., 2008 - Etude des cochenilles farineuses Planococcus citri (Risso) et Planococcus ficus (Signoret) en viticulture: Systématique, biologie et lutte Intégrée. MS thesis in Biological Control and Integrated Pest Management. National Agronomic Institute of Tunisia, University of Carthage, Tunis, Tunisia.

MANSOUR R., GRISSA LEBDI K., LA TORRE I., ZAPPALÀ L., RUSSO A., 2009 - Preliminary study on mealybugs in two vineyards of the Cap-Bon Region (Tunisia). - Tunisian J. Plant. Protec. 4:185-196.

MANSOUR R., MAZZEO G., LA PERGOLA A., GRISSA LEBDI K., RUSSO A., 2011 - A survey of scale insects (Hemiptera: Coccoidea) and tending ants in Tunisian vineyards. J. Plant. Protec. Res. 51: 197203.

MOGHADDAM M., 2006 - The mealybugs of southern Iran (Hem.: Coccoidea: Pseudococcidae). - J. Entomol. Soc. Iran 26: 1-11.

SAITOU N., NEI M., 1987 - The neighbor-joining method: a new method for reconstructing phylogenetic trees. - Mol. Biol. Evol. 4: 406-425.

STATSOFT Inc., 2004 - Statistica (data analysis software system) version 7. StatSoft, Inc., Tulsa, Oklahoma, USA.

TAMURA K., PETERSON D., PETERSON N., STECHER G., NEI M.,
KUMAR S., 2011 - MEGA5: Molecular Evolutionary Genetics Analysis using Maximum Likelihood, Evolutionary Distance, and Maximum Parsimony Methods. - Mol. Biol. Evol. 28: 2731-2739.

TRANFAGLIA A., TREMBLAY E., 1982 - A morphological comparison between Planococcus citri (Ris.), Planococcus ficus (Sign.) and their F1 hybrids. - Entomotaxonomia 4: 1-5.

TRJAPITZIN S.V., TRJAPITZIN V.A., 1999 - Parasites of mealybugs (Homoptera, Pseudococcidae) on cultivated grapes in Argentina, with description of a new species of the genus Aenasius Walker (Hymenoptera, Encyrtidae). - Entomol. Rev. 79: 386-390.

TSAI C.W., ROWHANI A., GOLINO D.A., DAANE K.M., ALMEIDA R.P.P., 2010 - Mealybug transmission of grapevine leafroll viruses: an analysis of virus-vector specificity. Phytopathology 100: 830-834.

WALSH P.S., METZQUER D.A., HIGUCHI R., 1991 - Chelex 100 as a medium for single extraction of DNA for PCR-based typing from forensic material. - Biotechniques 10: 506-512.

WALTON V.M., KRÜGER K., SACCAGGI D.L., MILLAR I.M., 2009 - A survey of scale insects (Sternorryncha: Coccoidea) occurring on table grapes in South Africa. - J. Insect Sci. 9: 47.

WILLIAMS D.J., WATSON G.W., 1988 - The Scale Insects of the Tropical South Pacific Region, Part 2: The Mealybugs (Pseudococcidae). CAB International Institute of Entomology, London, U.K.

WILLIAMS D.J., GRANARA DE WILLINK M.C., 1992 - Mealybugs of Central and South America, Second Part. CAB International Institute of Entomology, London, U.K. 